\title{
Facile Chemical Processing of Geloina coaxans Shell and Sodium dihydrogen Phosphate as Precursors to Produce Hydroxyapatite
}

\author{
Pepi Helza Yanti*, Resti Resmalina \\ Chemistry Department, Faculty of Mathematics and Natural Science, Universitas Riau \\ Pekanbaru 28293 \\ *Corresponding author: pepihelzayanti@lecturer.unri.ac.id
}

Received: May 2020; Revision: June 2020; Accepted: January 2021; Available online: February 2021

\begin{abstract}
This paper reports the synthesis of hydroxyapatite from Geloina coaxans shell and sodium dihydrogen phosphate as precursors by facile and simple method. Firstly, Geloina coaxans shell calcined at $1000{ }^{\circ} \mathrm{C}$ for 12 hours to produce lime or $\mathrm{CaO}$. The chemical composition of Geloina coaxans shell calcined was analyzed using the XRF technique, and the result shows that the main component of Geloina coaxans shell calcined was calcium. Synthesis of hydroxyapatite has been done with stirring and aging time parameters and molar ratio of precursors was 1,67 . The XRD patterns showed a specific peak of hydroxyapatite that appeared at $2 \theta=31.8^{\circ}$ and based on the XRD results on the aging time indicated that the rate of growth of HAp crystals was better and faster at aging for 12 hours. The crystal size of HAp obtained was $37 \mathrm{~nm}$. The FTIR spectra of hydroxyapatite showed characteristics of hydroxyl and phosphate bands in sample spectra. The morphology of hydroxyapatite synthesized also was examined by SEM and the results showed spherical morphology.
\end{abstract}

Keywords: Hydroxyapatite, aging, morphology

DOI: https://doi.org/10.15408/jkv.v6i2.15962

\section{INTRODUCTION}

Hydroxyapatite $\left[\mathrm{Ca}_{10}\left(\mathrm{PO}_{4}\right)_{6}(\mathrm{OH})_{2}\right]$, or $\mathrm{HAp}$ is one of calcium phosphate with ratio $\mathrm{Ca} / \mathrm{P}$ 1.67. It's a bioactive and biocompatible bioceramic (Hui et al., 2010) that having similar minerals phase in the natural bone. This biomaterial has many applications that cause many works in these research fields. The specific physical and chemical properties such as crystalline size, particle size, and morphology of HAp nanoparticles be a major topic and play a key role in several applications as adsorbent, catalyst (Bouka et al., 2016), drug delivery, and implant application. Further, it is important to note that crystalline size, particle size, surface area, and morphology of HAp nanoparticles play a key role.

Synthesis of hydroxyapatite can be conducted with several methods and types of precursors. Recently, the optimization of natural resources has attracted attention due to several reasons, such as abundant materials, non-toxic, easy to process with simple processing, and good results. Natural resources such as limestone, mollusk shells, animal bone have been converted as starting material on synthesis biomaterial hydroxyapatite. Many of wastes of Mollusk shell have been processed as calcium precursor on synthesis hydroxyapatite. Shavandi et al., (2014) has synthesized nano-hydroxyapatite from mussel shell with microwave method, oyster shells also have processed to produce hydroxyapatite with the wet method (Rujitanapanich et al., 2014), Macoma balthica (Felsen et al., 2015), and abalone shell (Chen et al., 2015)

This paper presents, utilization of mollusk shell Geloina coaxans shell from Riau Province as source calcium combined with $\mathrm{NaH}_{2} \mathrm{PO}_{4}$ to produce synthetic nanohydroxyapatite. $\mathrm{NaH}_{2} \mathrm{PO}_{4}$ is one of phosphate source can be used on synthesis HAp. The coprecipitation method was used due to simple, easy, and can be done at room temperature. High yields, low energy consumption, 
homogenous mixing, and nanophase particle size control was also a reason to choose this method. Reaction parameters such as $\mathrm{pH}$, concentration, physical parameters like stirring time, and aging time very influence the results of the sample synthesized. In this work, stirring time and aging time were reaction parameters chosen to learn the crystallinity of hydroxyapatite that synthesis at $\mathrm{pH}$ reaction was 11.

\section{MATERIALS AND METHODS Materials}

Geloina coaxans shell, sodium dihydrogen phosphate, or $\left(\mathrm{NaH}_{2} \mathrm{PO}_{4}\right)$ (Merck), ammonium hydroxide solution $\left[\mathrm{NH}_{4} \mathrm{OH}\right]$ (Merck), double distilled water (DDW), Whatman 42.

\section{Synthesis Procedure}

Sample Geloina coaxans shell or GCS was calcined at $1000{ }^{\circ} \mathrm{C}$ for 12 hours to produce lime. The calcined GCS was treated using DDW to produce $1 \mathrm{M}$ of $\mathrm{Ca}(\mathrm{OH})_{2}$. The next step, $\mathrm{NaH}_{2} \mathrm{PO}_{4}$ or sodium dihydrogen phosphate solution $0.6 \mathrm{M}$ was added dropwise to $\mathrm{Ca}(\mathrm{OH})_{2}$. $\mathrm{pH}$ was adjusted at 11 with $\mathrm{NH}_{4} \mathrm{OH}$ solution and the stirring rate was adjusted at $300 \mathrm{rpm}$ for one hour. The obtained suspension was kept for 24 hours at room temperature. The next step, obtained suspension was filtered and dried for 2 hours at $105{ }^{\circ} \mathrm{C}$. The prepared powders were calcined for 1 hour at $900{ }^{\circ} \mathrm{C}$. The same procedures were also done for stirring time 30,120, 240, and 300 minutes and aging time for 12,36, and 48 hours. Synthesized samples were characterized using XRD, FTIR, and SEM respectively.

\section{RESULTS AND DISCUSSION}

Calcination is the thermal decomposition of minerals to produce its metal oxide below of it's melting point. Geloina coaxans shell was calcined at $1000{ }^{\circ} \mathrm{C}$ for 12 hours to produce lime or $\mathrm{CaO}$. Data of XRD analysis were collected in the $2 \theta$ with range $5^{\circ}$ to $80^{\circ}$ using $\mathrm{Cu}-\mathrm{K} \lambda$ radiation $(\lambda=$ $1.5406 \AA$ A). XRD analysis was done to learn the mineral phases of the sample. The obtained data were compared to standard patterns or JCPDS. The crystallite sizes were calculated by using the Debye Scherrer equation. The result of $\mathrm{XRD}$ is shown in Figure. 1.

Based on Figure 1, the calcination process of Geloina coaxans shell after sintering $1000{ }^{\circ} \mathrm{C}$ for 12 hours has produced lime or $\mathrm{CaO}$. The XRD pattern has shown a specific peak of lime. The highest peak appeared at $2 \theta$ $=37,5^{\circ}$ compared to JCPDS (No. 37-1497), other peaks of lime also seen at $2 \theta=54.0^{\circ}$; $32.3^{\circ} ; 67.4^{\circ}$, and $64.3^{\circ}$. The low peaks at $34.2^{\circ}$ and $18.1^{\circ}$ has also proved appearance another phase portlandite or $\mathrm{Ca}(\mathrm{OH})_{2}$ in minor percentage. These peaks are suitable with JCPDS (No 44-148). These minerals can be caused by interaction of lime with water vapor. This phenomenon is related to the hygroscopic properties and less stability of lime to room temperature and pressure, that can react spontaneously at air moisture.

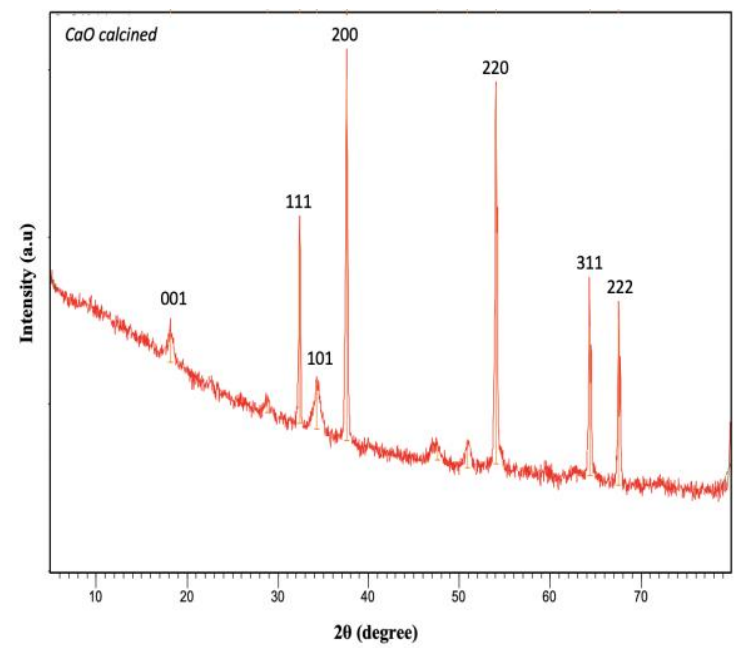

Figure 1. X-ray diffraction patterns of Geloina coaxans shell calcined $1000^{\circ} \mathrm{C}$ for 12 hours

The reaction of this process in the equation below

$$
\mathrm{CaCO}_{3(\mathrm{~s})} \longrightarrow \mathrm{CaO}_{(\mathrm{s})}+\mathrm{CO}_{2(\mathrm{~g})}
$$

Previous research, Zhong et al. (2017) calcined abalone shell at $1000{ }^{\circ} \mathrm{C}$ while mussel shell calcined to produce lime at $1000{ }^{\circ} \mathrm{C}$ for 3 hours (Edralin et al., 2017). Rujitanapanich et al. (2014) also converted oyster shells to lime with several calcination temperatures at 1000 , 1100 , and $1200{ }^{\circ} \mathrm{C}$ for 2 hours, and concluded that sintering at $1200{ }^{\circ} \mathrm{C}$ for 2 hours have produced lime successfully. Yoosuk et al. (2010) also explained $\mathrm{CaCO}_{3}$ can be decomposed at $800{ }^{\circ} \mathrm{C}$ to produce lime. 
The chemical compositions analysis of Geloina coaxans shell calcined was also done by using the XRF technique. The XRF analysis was conducted to estimate the qualitative and quantitatively chemical composition of GCS calcined. The results of the XRF analysis can be seen in Table 1.

The result show that the major component of Geloina coaxans shell calcined was calcium oxides and also consist of several elements. The high component of $\mathrm{CaO}$ is related to the presence of calcium carbonate, $\left(\mathrm{CaCO}_{3}\right)$ which is the major component of the GCS confirmed by the XRD results and there are no characteristic peaks of $\mathrm{CaCO}_{3}$. The high intensity and narrow peak of XRD results proved the decomposition has occurred athough there is another phase portlandite seen with minor percentage. Previous research, the $\mathrm{CaCO}_{3}$ of Mussel shell was also converted to pure calcium oxide after calcined at $900{ }^{\circ} \mathrm{C}$. The results proved by measured with XRD technique (Shavandi et al., 2014)

Table 1. Chemical composition of Geloina coaxans shell calcined with XRF analysis

\begin{tabular}{cc}
\hline $\begin{array}{c}\text { Chemical Composition } \\
\text { (Formula) }\end{array}$ & Percentage (\%) \\
\hline $\mathrm{CaO}$ & 97.228 \\
$\mathrm{SiO}$ & 0.858 \\
$\mathrm{Ag}_{2} \mathrm{O}$ & 0.651 \\
$\mathrm{Al}_{2} \mathrm{O}_{3}$ & 0.543 \\
$\mathrm{SrO}$ & 0.338 \\
$\mathrm{In}_{2} \mathrm{O}_{3}$ & 0.298 \\
$\mathrm{Fe}_{2} \mathrm{O}_{3}$ & 0.036 \\
$\mathrm{TiO}_{2}$ & 0.032 \\
$\mathrm{MnO}_{2}$ & 0.003 \\
$\mathrm{~V}_{2} \mathrm{O}_{5}$ & 0.002 \\
\hline
\end{tabular}

\section{Synthesis of Hydroxyapatite}

Precipitation method synthesis is the simple and frequently used on synthesis hydroxyapatite or HAp. The peak of the XRD pattern shown the result of the chemical reaction of calcium and phosphate precursors at $\mathrm{pH}$ reaction was 11 at several of stirring time. The $\mathrm{pH}$ and micro-environment of synthesis are usually carried out at alkaline $\mathrm{pH}$. The common $\mathrm{pH}$ is 10 . The chemical processing of precursors phosphate or $\mathrm{PO}_{4}$ and calcium or $\mathrm{Ca}$ is a very influenced crystallinity of hydroxyapatite. Several reaction parameters also influence the formation of hydroxyapatite.
Crystallinity and purity of hydroxyapatite synthesized are variable. In the first analysis, the prepared sample was analyzed by XRD to learn the chemical phase, crystallinity, and purity. The analysis was carried out by using monochromatic $\mathrm{Cu}-\mathrm{K} \alpha$ radiation $(\lambda=1.154060$ $\mathrm{nm})$. The XRD result of synthesized hydroxyapatite was shown in Figures 2 and 3 for stirring time and aging time respectively.

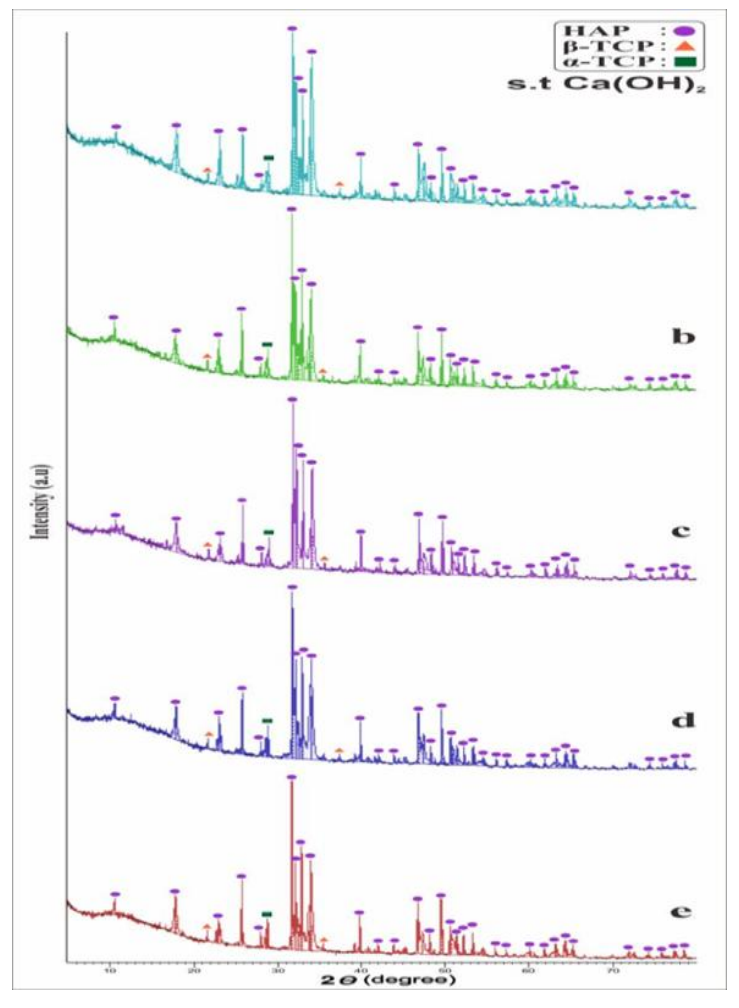

Figure 2. X-Ray Diffraction patterns of HAp or hydroxyapatite at stirring time for (a) 30, (b) 60, (c) 120 , (d) 240 , and (e) 360 minutes via precipitation method

The XRD pattern in Figure 2 shows the effect of stirring time on synthesis hydroxyapatite at $30,60,120,240$, and 360 minutes. All of the samples describe the specific peaks of hydroxyapatite and have similar trends but with different intensities. The highest peak of hydroxyapatite was for stirring time 60 minutes. The $2 \theta$ appeared at $=$ $31.8^{\circ}$, and others peaks were at $2 \theta=32.9^{\circ}$; $34.0^{\circ} ; 49.5^{\circ} ; 46.7^{\circ}$, were suitable with JCPDS pattern (No.09-432) and miller index were [211] respectively. The percentage of hydroxyapatite prepared at stirring time for 60 minutes was 95,07\%, while another research, Abdi and Murtaza (2014) produced powder hydroxyapatite for $24 \mathrm{~h}$. The narrow and sharp peaks indicated well-growth crystals. The data 
explained physical characteristic such as stirring time influence the movement and bonding of ions as the effect of reaction and collision to produce HAp. Collision frequency is the crucial factor on synthesis because its' reflect the number of collisions per second to gain hydroxyapatite.

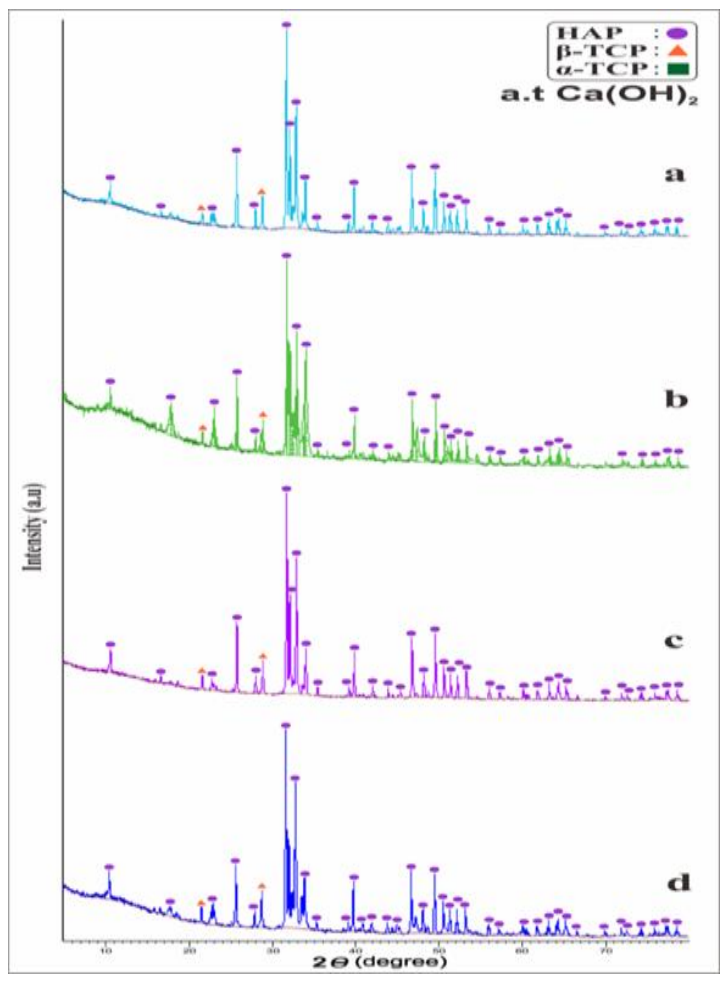

Figure 3. X-Ray Diffraction patterns of HAp or hydroxyapatite at aging time for (a) 12 , (b) 24 , (c) 36, (d) 48 hours via precipitation method

Figure 3. represents of XRD pattern of hydroxyapatite synthesized by aging time at $12,24,36$, and 48 hours. Aging time was another factor influence the formation of hydroxyapatite. The XRD result of aging time for 12 hours shows the intensity is higher than others and revealed a characteristic peak of
HAp at $2 \theta=31.7^{\circ}$ are suitable with JCPDS (No 09-0432) and others peak at $2 \theta=32.8^{\circ}$; $49.4^{\circ} ; 34.0^{\circ}$; and $25.8^{\circ}$. The percentage of HAp produced was $95,83 \%$. Based on the XRD pattern, another chemical phase of calcium phosphate also detected with minor intensity. $\beta$-TCP ( $\beta$-tricalcium phosphate) phases appeared at $2 \theta=21.7^{\circ}$ and $28.8^{\circ}$, correspond to JCPDS of $\beta$-TCP (No 09-0169). The percentage of crystallinity aging time for 24, 36, and 48 hours was 95.07; 94.90; and $94,91 \%$. These results explain that the percentage of hydroxyapatite decreased with increasing aging time, and the results indicate that the rate of growth of HA crystals was better and faster at aging for 12 hours. The data and observations proved the increase of the aging time led to the smaller crystallite size. Bang and Othman (2014) explained the aging time for 24 hours was an excellent condition to obtain thermal stability of hydroxyapatite which is calcined at $1200^{\circ} \mathrm{C}$ for one hour.

The mean crystallite size of the sample was calculated by Debye Schererr formula in Equation below

$$
D=\frac{K \lambda}{\beta \cos \theta}
$$

In this formula $\mathrm{K}$ is the Schererr constant which is taken as $0.89, \lambda$ is the wavelength of $\mathrm{Cu}-\mathrm{Ka}$, while $\beta$ is for the fullwidth at half maximum (FWHM) and is stands for diffraction angle $\theta$. The average the crystallite size at stirring time for 60 minutes and aging time for 24 hours was $37 \mathrm{~nm}$ while hydroxyapatite prepared for aging time 12 hours was $27 \mathrm{~nm}$. Abidi and Murtaza (2014) found the crystallite size of HAp powder around $8.47-24.47 \mathrm{~nm}$.

Reaction of this process shown below:

$$
\begin{aligned}
& \mathrm{CaO}(\mathrm{s})+\mathrm{H}_{2} \mathrm{O}(\mathrm{l}) \longrightarrow \mathrm{Ca}(\mathrm{OH})_{2}(\mathrm{aq}) \\
& \mathrm{NaH}_{2} \mathrm{PO}_{4}(\mathrm{~s})+\mathrm{H}_{2} \mathrm{O}(\mathrm{l}) \longrightarrow \mathrm{NaH}_{2} \mathrm{PO}_{4}(\mathrm{aq}) \\
& 10 \mathrm{Ca}(\mathrm{OH})_{2}(\mathrm{aq})+6 \mathrm{NaH}_{2} \mathrm{PO}_{4}(\mathrm{aq})+\mathrm{NH}_{4} \mathrm{OH}(\mathrm{aq}) \longrightarrow \mathrm{Ca}_{10}\left(\mathrm{PO}_{4}\right)_{6}(\mathrm{OH})_{2}(\mathrm{~s})+\mathrm{NH}_{4} \mathrm{OH}(\mathrm{l})+6 \mathrm{NaOH}(\mathrm{l})
\end{aligned}
$$

FTIR spectroscopy was examined to learn functional groups of hydroxyapatite and support the data obtained with the XRD instrument. The results of FTIR analysis can 
be seen in (Figure 4 and Table 2). The result of FTIR at stirring time for 60 minutes is shown in Figure 4. Phosphate group appeared at $570,962,1041$, and $1084 \mathrm{~cm}^{-1}$ while the vibration of the hydroxyl group assigned with a peak at $3642 \mathrm{~cm}^{-1}$. Mohandes et al., (2014) explained that the vibration of $557-568 \mathrm{~cm}^{-1}$ are attributed to the bending vibrations of phosphate groups. Candidato et al. (2015) also illustrated the appearance of phosphates at 567 and $1036 \mathrm{~cm}^{-1}$, while the hydroxyl band at $3570 \mathrm{~cm}^{-1}$. he band modes of hydroxyl group were also detected at 3567 and $3420 \mathrm{~cm}^{-1}$ respectively (Chen et al., 2015; Swain and Sarkar, 2011). Additionally, the band at 1400 $\mathrm{cm}^{-1}$ was assigned to the vibration of $\mathrm{CO}_{3}{ }^{2-}$. The vibration is caused by the reaction process without a vacuum condition. Edralin et al., (2017); Sasikumar (2010) also detected carbonate group at $1417 \mathrm{~cm}^{-1}$ and $1500 \mathrm{~cm}^{-1}$.

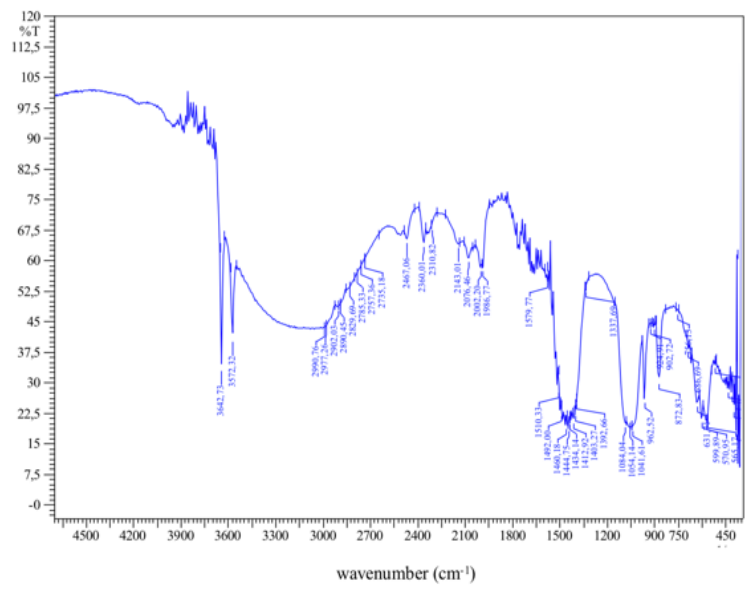

Figure 4. FTIR spectra of hydroxyapatite at stirring time for 60 minutes consist of characteristic peaks of phosphate, hydroxyl, and carbonate group.

Table 4. Identification functional groups of hydroxyapatite with Fourier Transform Infrared Spectroscopy (FTIR) with stirring time for 60 minutes

\begin{tabular}{ccc}
\hline \multirow{2}{*}{$\begin{array}{c}\text { Functional } \\
\text { Group }\end{array}$} & \multicolumn{2}{c}{ Wavenumber $\left(\mathbf{c m}^{-\mathbf{1}}\right)$} \\
\cline { 2 - 3 } & Results & $\begin{array}{c}\text { Candidato } \\
\text { et al., 2015 }\end{array}$ \\
\hline $\mathrm{PO}_{4}{ }^{3-}$ & 570 & 567 \\
$\mathrm{PO}_{4}{ }^{3-}$ & 962 & - \\
$\mathrm{PO}_{4}{ }^{3-}$ & 1041 & 1036 \\
$\mathrm{PO}_{4}{ }^{3-}$ & 1081 & - \\
$\mathrm{OH}^{2-}$ & 3571 & 3570 \\
$\mathrm{CO}_{3}{ }^{2-}$ & 1412 & 1400 \\
\hline
\end{tabular}

Morphology of hydroxyapatite was examined by Scanning Electron Microscopy
(SEM) with $10000 x$ magnification at the stirring time for 60 minutes and aging time for 12 hours. The SEM images showed agglomeration and quite uniform spherical particles as shown in Figure 5. Previous research Swain and Sarkar (2011) also demonstrates the spherical powders of prepared hydroxyapatite after aging one hour.

Morphology of particle can influence the activity and application of hydroxyapatite. Previous research has shown that shapes of hydroxyapatite play crucial roles in several applications, such as adsorbent or drug delivery. The shape of particle hydroxyapatite can influence the activity of cells.

Recently, the usability of HA nanoparticles (n-HA) against several type of cancer cells was reported. Hydroxyapatite (HAp) powder with various morphologies has been successfully synthesized and examined their influence on human colon cancer HCT116 cell inhibition. The results showed that the inhibition of cellular activity reached 80 percent of nanoHAp in the form of rods. The data revealed the morphology of hydroxyapatite play crucial role in on cellular activities (Dey et al., 2014).

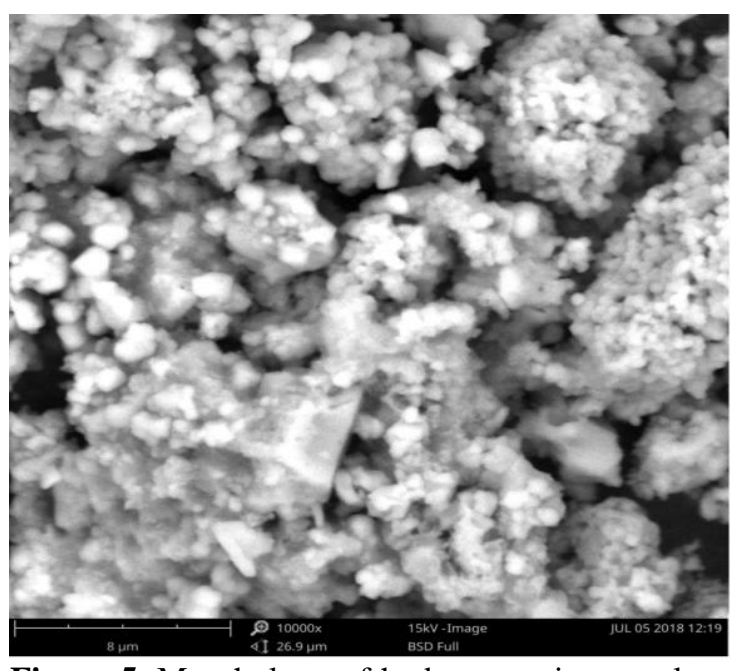

Figure 5. Morphology of hydroxyapatite sample at stirring time for 60 minutes and aging time for 12 hours.

\section{CONCLUSION}

In this research, physical parameters such as stirring time and aging time can influence the crystallinity and purity of hydroxyapatite synthesized. The results showed that both reaction parameters are effective in increasing the reaction rate on the formation of hydroxyapatite powder. Based on 
the XRD results on the aging time indicated that the rate of growth of HA crystals was better and faster at aging for 12 hours. The data and observations also indicated the shorter the aging time led to the smaller crystallite size was $37 \mathrm{~nm}$. Functional group analysis with FTIR instrument proved the specific band of hydroxyapatite appeared at a characteristic peak of hydroxyapatite while SEM analysis showed agglomeration and quite uniform sphericalparticles.

\section{REFERENCES}

Abidi S, Murtaza Q. 2014. Synthesis and characterization of nano-hydroxyapatite powder using wet chemical precipitation reaction. Journal Mater Sci Techno. (3): 1-4.

Bang LT, Othman R. 2014. Aging time and synthesis parameters of nanocrystalline single-phase hydroxyapatite produced by a precipitation method. Ceramic Silikaty. 58(2):157-164.

Boukha Z, Jonatan G, Guttirez O. 2016. Synthesis, characterization, and behavior of $\mathrm{Co} / \mathrm{HAp}$ catalyst in the oxidation of 1,2dichloroethane. Materials. 190: 125-136.

Candidato RT, Sokolowski P, Pawlowski L, Denoirjean. 2015. A preliminary study of hydroxyapatite coating synthesis using solution precursor plasma spraying. Surface \& Coating Technology. (277): 242-250.

Chen J, Wen Z, Zhong S, Wu J, Zhang Q. 2015.Synthesis of hydroxyapatite nanorods from abalone shells via hydrothermal solidstate conversion. Materials and Design. (87):445- 449 .

Dey S, Das M, Balla VK. 2014. Effect of hydroxyapatite particle size, morphology and crystallinity on proliferation of colon cancer HCT116 cells. Materials Science and Engineering C 39. 336-339.

Edralin EJM, Jony LG, Francis M, Rosa D, Punzalan ER. 2017. Sonochemical synthesis, characterization, and photocatalytic properties of hydroxyapatite nano-rods derived from mussel shells. Materials Letters. 196: 33-36.

Mohandes F, Salavati-Niasari M, Fathi M, Fereshteh Z. 2014. Hydroxyapatite nanocrystals: Simple preparation, characterization, and formation mechanism. Materials Science and Engineering C.45: 29-36.

Trinkunaite-Felsen J, Prichodko A, Semasko M, Skaudžius R, Beganskienė A, Kareiva A. 2015. Synthesis and characterization of iron-doped/substituted calcium hydroxyapatite from seashell macoma balthica (L). Advanced Powder Technology. 300: 300-310.

Hui P, Meena SL, Singh G, Prakash S. 2010. Synthesis of hydroxyapatite bio-ceramic powder by hydrothermal method. Journal of Mineral and Materials Characterization and Engineering. (9): 30-43.

Rujitanapanich S, Kumpapan P, Wanjonoi P. 2014. Synthesis of hydroxyapatite from oyster shell via precipitation. Materials Science and Engineering. (56) : 112-117.

Shavandi A, Bekhit AE, Ali Z, Sun Z. 2014. Synthesis of nano-hydroxyapatite from waste mussel shells using a rapid microwave method. Material Chemistry and Physics:110 .

Swain SK, Sarkar, D. 2011. A comparative study: Hydroxyapatite spherical nanopowders and elongated nanorods. Ceramics International. (37)7: 2927-2930.

Yoosuk B, Parncheewa U, Buppa P, Pawnprapa K. 2010. Improving transesterification activity of $\mathrm{CaO}$ with hydration technique. Bioresource Technology. 101: 3784 - 3786.

Zhong S, Zhenliang W, Chen J, Qian L, Xuetao S, Shinnjyh D, Qiqing Z. 2017. Effect for rapid conversion from abalone shells to hydroxyapatite nanosheets by ionic surfactants. Materials Science and Engineering. C77: 708 - 712 . 